\title{
PERCEPTIONS OF CLIMATE VARIABILITY AND DETERMINANTS OF FARMERS'ADAPTATION STRATEGIES IN THE HIGHLANDS OF SOUTHWEST CAMEROON
}

\author{
Ngoe, M. ${ }^{1}-$ Zhou, L. ${ }^{*}{ }^{*}-$ Mukete, B. ${ }^{2}-$ EnJeMA, M. ${ }^{3}$ \\ ${ }^{1}$ College of Economics and Management, Nanjing Agricultural University, 1 Weigang, Nanjing \\ 210095, Jiangsu Province, China \\ ${ }^{2}$ College of Forestry, Beijing Forestry University, 35 Qinghua Dong Lu, Haidian District, \\ Beijing 100083, China \\ ${ }^{3}$ Faculty of Economics and Management, University of Buea, P. O. Box 63, Buea, Cameroon \\ *Corresponding author \\ e-mail:zhouli@njau.edu.cn; phone: +86-138-5173-1053 \\ (Received 25 $5^{\text {th }}$ Jun 2019; accepted $16^{\text {th }}$ Oct 2019)
}

\begin{abstract}
In Cameroon, climate variability largely controls agriculture related livelihood strategies This variability enhances environmental threats including deforestation, water scarcity and land degradation, which would affect these long and short-term livelihood strategies. This study examined farmers' perceptions of climate variability and the factors that influence various climate adaptation strategies in the highlands of Southwest Cameroon. Using local scale meteorological data from 1974 to 2014 and climate perception data collected from 355 households, in 22 rural villages through household surveys and 12 focus group discussions, descriptive statistics and logit regression model analyses were performed. Results showed $85.1 \%, 83.9 \%$ and $86.2 \%$ of the respondents to have observed changes in patterns of temperature, rainfall and number of rainy days. Results further showed household characteristics such as marital status (P-value 0.072) to influence the household decision of increasing in farm size more than gender of household head (P-value 0.221). Also, age of household head (P-value 0.086) influenced adoption of changing planting dates more than gender of household head (P-value 0.207) in a village at the $95 \%$ level of significance. This study will help policy makers educate local rural farmers on climate adaptation measures, impacts, and methods for increasing crop yields.
\end{abstract}

Keywords: climate variability, perception, adaptation strategies, logit model, smallholder farmers

\section{Introduction}

In Cameroon as in many other sub-Saharan African countries, climate variability exerts varying impacts especially on the agricultural sector. This is probably due to the fact that the majority of the local population mainly relies on rain-fed agriculture for a living (Mukete et al., 2017). Therefore, due to its sensitivity to rainfall and temperature anomalies, the agricultural sector would be adversely affected. These climate effects could likely lead to socioeconomic impacts particularly in the case of farmers whose livelihood (60\%-80\%) primarily depends on agriculture (Defang et al., 2017). Climate variability is often linked to differential land-maritime interactions which result into various impacts on human lives and livelihoods. Often attributed to changes in rainfall patterns or amount and shifts in thermal and wind regimes, this variation modifies local seasonal and annual water balances. These seasonal and annual water balances in turn influence the periodic distribution for which temperature and moisture conditions permit agricultural crop production (Mongi et al., 2010; Sonwa et al., 2017; Ndiaye et al., 2018). 
In many developing countries, local farmers continue to perceive climate variability as it exerts varying impacts on crop yields. Farmers have therefore developed various adaptation strategies which permit them adapt to this changing climate. But in order to adopt a particular climate adaptation strategy, farmers must first experience climate change before taking measures to adapt to these perceived changes. According to Oluwatusin (2014) and Mukete et al. (2017), these adaptations are interventions and adjustments which occur in order to take advantage of the opportunities or to manage the losses that take place as a result of any external change. From another perspective, IPCC (2012) refers to climate adaptation as the adjustments in natural or man-made systems in response to actual or expected climatic stimuli or their effects. The assessment of farmer adaptation strategies is necessary if the information required for managing climate risks, adaptation enhancement policy analysis and implementation is to be made available (Mukete et al., 2018a).

In this regard, several studies across Africa have examined climate perceptions, variability and farmer adaptation strategies. For instance, Tsegamariam (2018) showed that majority of farmers around Abeshege Woreda in Ethiopia had perceived a decrease in rainfall with an increase in temperatures during the past two decades. Here, farmers applied soil and water conservation, small scale irrigation, changing planting dates, improved crop and livestock varieties as adaptation strategies to climate variability. Using, the logit regression model, the authors observed farmer educational level, farm size, access to credit schemes, and family size to determine a farmer's decision to adopt climate adaptation strategies. Similarly, Gadédjisso (2015) showed about $85 \%$ of farmers in Togo, perceived increase in temperature and $85.58 \%$ a decrease in rainfall patterns within the past three decades. Farmer adaptation strategies included crop diversification, off-farm jobs, increase in farm size, change of planting date and planting of cycle crops. A multinomial logit analysis showed education level, farming experience, access to extension services, credit schemes, and climate information enhanced a farmer's adaptive capacity to climate variability.

In another study, Seid (2016) observed $96.3 \%$ of farmers in Western Ethiopia, had perceived an increase in temperature and $90.7 \%$ a decrease in the amount and timing of annual rainfall patterns between 2000 and 2015. In addition, average annual temperatures were found to have increased by about $0.096^{\circ} \mathrm{C}$ while annual rainfall had decreased by about $46.75 \mathrm{~mm}$ per year. According to the study, over $49.9 \%$ of the farmers have adopted climate adaptation approaches such as crop diversification, irrigation, improved crop varieties, adjusting planting dates and various soil conservation techniques like fallowing. In another study around the Vea Catchment of Ghana, Limantol et al. (2016) found, $90 \%$ and $94 \%$ of farmers believed that temperatures have increased and rainfall amounts, duration, intensity and number of rainy days have decreased. In this catchment area, farmers who rely on rain-fed agriculture adjusted to climate variability by varying crop types, crop rotation without fertilizer. Meanwhile, farmers who rely on irrigation offset climate variability with a greater use of fertilizer application. According to van der Veen (2013), 78\%, 69\% and $17 \%$ of farmers in the Ethiopian Highlands perceived an increased in temperatures and the level of precipitation was declining over the past 20 years. Farmers employed climate adaptation strategies such as crop diversification, various soil conservation methods like planting of trees, fallowing, irrigation, and changing planting dates. Using a multinomial logit (MNL) model, the farmer's level of education, age, wealth, access 
to credit schemes, agricultural extension services and climate change information respectively determined their choice of adaptation strategies.

In Cameroon, agriculture is the main stay of the country's economy, employing over $70 \%$ of the population (Kimengsi and Muluh, 2013; Balgah et al., 2016; Tabi et al., 2017). However, agricultural activities have been largely affected by fluctuations in local climate particularly rainfall and temperatures which affect both large scale and subsistence agriculture (Kimengsi and Tosam, 2013; Sonwa et al., 2017). Over the past four decades, lack of reliable quantitative data on agricultural activities and climate variability has been a major challenge for Cameroon's researchers. For instance, and according to Defang et al. (2017), farmers in Southwest Cameroon perceived climate variability as a late start and early cessation of rains, decrease intensity of rainfall, increase temperatures and intensity of the sun. The study also found majority of farmers to have adapted to climate impacts on plantain (Musa paradisiaca) and cassava (Manihot esculenta) by respectively treating suckers and cuttings with Mocap before and after sowing. MOCAP ${ }^{\circledR}$ is a granular systemic insecticide or nematicide containing $15 \% \mathrm{w} / \mathrm{w}$ ethoprophos which is applied to the soil. It is recommended for the reduction in wireworm damage, potato cyst nematode damage and incidence of Spraing, on all varieties of potatoes. Farmers also changed the cultivated cocoyam variety and planted trees in order to adapt to the impacts of climate change.

Similarly, Darota et al. (2017) observed $92 \%$ of the Kaka and $86 \%$ of Bulu tribes of Southern Cameroon to have perceived excessive rainfall and which occurs for a short period. Here, $53 \%$ of Kaka and $58 \%$ Bulu tribes, practiced off-farm activities to compensate for the low income resulting from low harvest due to climate variation. Other adaptation options included, crop diversification, early planting and harvesting as well as cultivating in upland and lowland areas. In another study carried out in the Santa Agrarian Basin of Cameroon's Western Highlands from 2001-2014, Zephania and Bonglam (2016) found farmers to have perceived decreasing rainfall with increasing temperatures and relative humidity trends. The study found over $90 \%$ of these local farmers to be aware of climate variability. Meanwhile, about $8.2 \%$ were yet to adopt adaptation strategies which would lead to reduced negative impacts, increased crop resilience and integrated animal farming systems. Relatedly, Balgah et al. (2016) found over $97 \%$ farmers in North West Cameroon to have demonstrated contextual knowledge of climate variability, as they reported increased rainfall, prolonged dry seasons and changes in rainfall patterns. The study also indicated changing planting dates, and mixed cropping as local farmer adaptation strategies. In another study using primary weather and household livelihood survey data, Mukete et al. (2017) examined the vulnerability and adaptability of women to climate changes in the Rumpi highlands of southwest Cameroon. The study found decreasing amounts of rainfall, receding forests, increasing temperatures, water scarcity, and increasing costs of living. The study also found adjusting sowing dates, adopting petty trading and changing cropping patterns as adaptation strategies applied by these local women.

Although agricultural activity has been largely affected by climate anomalies particularly rainfall and temperature with varying effects on both large and small-scale agriculture, long-term sustainability initiatives and studies are rare. These rare studies such as Defang et al. (2017) and Mukete et al. (2017) have mainly examined farmers' perceptions of climate change and adaptation options without analyzing the various factors that may determine a farmer's choice of climate adaptation measures. Aside farmers' perceptions of climate change and adaptation measures, the present study 
analyzes the various factors that may determine a farmer's choice of climate adaptation measures in the highlands of southwest Cameroon.

This study bridges that knowledge-gap as it assesses farmers' perceptions of climate variability and the factors that determine their choice of adaptation strategies. This baseline information may help improve macro-level poverty estimates and serve as an input into agricultural policy. It may also serve as a knowledge platform for effective collaboration between agriculture dependent communities, stakeholders and policy makers to design effective rural community-based agricultural management and rural development programs aimed at reducing climate change impacts and improve crop yields. This will create the possibility of building a broad knowledge base and offer adaptation and mitigation strategies to help farming households cope with climate changes.

\section{Materials and methods}

\section{Study area}

This study was carried-out in part of the highlands of Southwest Cameroon located along latitude $4^{\circ} 51^{\prime} 26^{\prime \prime} \mathrm{N}$ and longitude $9^{\circ} 07^{\prime} 15^{\prime \prime} \mathrm{E}$ in Ndian Division (see Fig. 1).

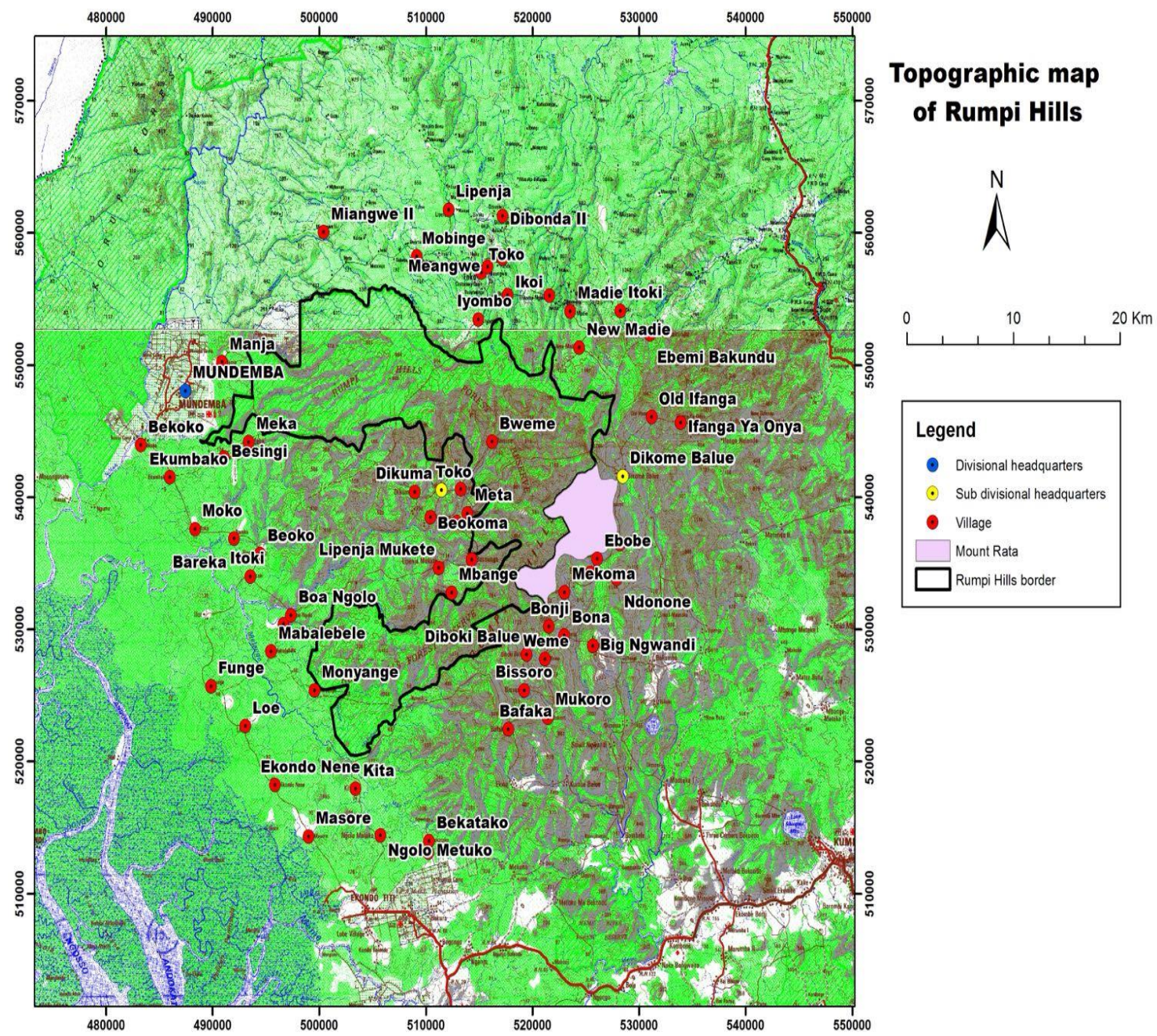

Figure 1. Map of study area 
Majority of the population is rural with over $90 \%$ involved in agricultural activities growing food crops (cocoyam, plantains, cassava etc.) and cash crops (oil palm, cocoa and rubber tree etc.). Local communities are also engaged in other livelihood activities such as animal husbandry, petit trading and the harvesting of Non-timber forest products (NTFPs) mostly as off-season jobs. NTFPs are items of biological origin which are not timber and wood, obtained from forests, plantations, woods, fallows and other agroforestry systems. In the highlands of southwest Cameroon, NTFPs are primarily land snails, bitter cola, bush mango, njansang, bush pepper and various edible mushrooms (Ofundem et al., 2017; Mukete et al., 2018c).

\section{Data collection}

Data were collected between December 2016 and May 2017 through focus group discussions (FGDs) and individual questionnaires. The number of households in each village was obtained from the local village chiefs because official census data are lacking. In villages with less than 25 households, only semi-structured and open-ended questionnaires through a door to door survey were used. Additionally, villages with more than 25 households were divided into groups for easy implementation of FGDs. The number of participants in an FGD was limited to 10 and included volunteers and or randomly selected farmers of at least 18 years old (according to Cameroon Law). Their national identity cards were verified and in cases where this was unavailable, recommendation was sought from the local village chief or his representative. In instances where potential participants were unable to effectively communicate in English language, "Pidgin English" or Oroko dialect was used by the first author to ensure proper understanding. The interview captured at least $90 \%$ of the households per village giving a total of 355 interviews of households across the 22 adjacent villages (Mukete et al., 2018c).

The household was the basic unit for this study and it refers to a group of people living together in the same house who regularly cook and eat from the same pot. Here, questions were centered on household head demographic characteristics, socioeconomic activities, perception of climate variability and adaptation methods employed. Meteorological data from 1974-2014 were collected from the Pamol Plantations Plc weather station located in Mundemba, Ndian division of southwest Cameroon. Pamol Plantations Plc is an agroindustrial company specialized in palm oil production and growth of natural rubber. Stata 13.0 was used for the logit regression model analysis to identify the determinants of farmer adaptation strategies. Meanwhile, Microsoft Excel for Windows 10 was used to deduce the meteorological data per parameter. The logit model was employed because it considers the relationship between a binary dependent variable and a set of independent variables, be they binary or continuous (Eqs. 1 and 2; Greene, 2018).

$$
\log \left[P_{\mathrm{i}} /\left(1-P_{\mathrm{i}}\right)\right]=\log \left(P_{\mathrm{i}}\right)=\beta_{0}+\beta_{1} X_{\mathrm{i}}
$$

where $P_{i}$ is the probability of perceiving a variability in climate and $X_{i}$ an independent variable Therefore, the parameter $\beta_{1}$ gives the log odds of the dependent variable and $\beta_{0}$ is a constant.

The probability of occurrence of an event relative to non-occurrence is called odds ratio and is given by

$$
P_{i} /\left(1-P_{i}\right)=\exp \left(\beta_{0}+\beta_{1} X_{i}\right)
$$


The dependent variables are the adaptation strategies which include increase in farm size, use of external inputs (labour, pesticides, fertilizers, and manure), crop diversification, change of planting dates, off-farm activities and NTFPs harvesting. Meanwhile, the independent variables are the household characteristics such as gender, age, educational level, inhabitants, and marital status of farmer.

\section{Results}

\section{Household characteristics of respondents}

Household characteristics showed $54.4 \%$ of the respondents to be males and $45.6 \%$ females. About $10.4 \%$ of the respondents were aged $21-30$ years, $81.4 \%$ aged between 31-60 years and $8.2 \%$ were over 60 years. Similarly, $79.7 \%$ were indigenous while $20.3 \%$ were migrants (Table 1). Also, $20.8 \%$ had no education, 54.4\% had only primary education, $21.7 \%$ secondary education and only $3.1 \%$ had university education.

Table 1. Household characteristics of respondents

\begin{tabular}{c|c|c}
\hline Variable & Frequency & Percentage \\
\hline Gender & 193 & 54.4 \\
Male & 162 & 45.6 \\
Female & & \\
Age & 37 & 10.4 \\
$21-30$ & 113 & 31.8 \\
$31-40$ & 98 & 27.6 \\
$41-50$ & 78 & 22 \\
$51-60$ & 29 & 8.2 \\
Above 61 & 283 & \\
Inhabitants & 72 & 79.7 \\
Indigenous & & 20.3 \\
Migrants & 74 & 20.8 \\
Educational level & 193 & 54.4 \\
No education & 77 & 21.7 \\
Primary & 11 & 3.1 \\
Secondary & & \\
University & 205 & 57.7 \\
Marital status & 102 & 28.7 \\
Married & 19 & 5.4 \\
Single & 29 & 8.2 \\
Divorce & & \\
Widowed & &
\end{tabular}

\section{Economic activity}

Results showed $51 \%$ of the respondents were involved in agricultural activities, $19.4 \%$ in petty businesses, and $13.2 \%$ in forestry resources harvesting (see Table 2). 
Table 2. Economic activity of respondents

\begin{tabular}{c|c|c|c}
\hline Sector & Response & Frequency & Percentage \\
\hline \multirow{2}{*}{ Agricultural } & Yes & 181 & 51.0 \\
& No & 174 & 49.0 \\
\hline \multirow{2}{*}{ Public transport } & Yes & 35 & 9.9 \\
& No & 320 & 90.1 \\
\hline \multirow{2}{*}{ Petty business } & Yes & 69 & 19.4 \\
& No & 286 & 80.6 \\
\hline \multirow{2}{*}{ Forestry } & Yes & 47 & 13.2 \\
& No & 308 & 86.8 \\
\hline \multirow{2}{*}{ Other } & Yes & 23 & 6.5 \\
& No & 332 & 93.5 \\
\hline
\end{tabular}

\section{Farmer perception of climate variability}

About $73.5 \%, 11.5 \%$ and $15 \%$ of the respondents had perceived an increase, decrease and no changes in temperature patterns. Similarly, $77.5 \%, 6.5 \%$ and $16 \%$ had perceived a decrease, an increase and no change in rainfall patterns respectively. Also, results showed $61.4 \%, 25.1 \%$ and $13.5 \%$ thought the number of rainy days had decreased, increased and had not changed (Table 3).

Table 3. Farmers' perception on climate variability

\begin{tabular}{c|c|c|c}
\hline Climate parameters & Variability & Frequency & Percentage \\
\hline \multirow{3}{*}{ Temperature patterns } & Increase & 261 & 73.5 \\
& Decrease & 41 & 11.5 \\
& No change & 53 & 15 \\
\hline \multirow{3}{*}{ Rainfall patterns } & Increase & 23 & 6.5 \\
& Decrease & 275 & 77.5 \\
& No change & 57 & 16 \\
\hline \multirow{3}{*}{ Number of rainy days } & Increase & 89 & 25.1 \\
& Decrease & 218 & 61.4 \\
& No change & 49 & 13.5 \\
\hline
\end{tabular}

\section{Variation in mean annual temperature patterns}

Mean annual temperature had increased by $0.015{ }^{\circ} \mathrm{C}$ per year with 2009 recording the highest mean annual temperatures. The $\mathrm{R}$ squared value shows a $16 \%$ variation in temperatures (see Fig. 2).

\section{Variation in mean annual rainfall}

Mean annual rainfall decreases by about $1.7445 \mathrm{~mm}$ per year with 1983 having the highest mean annual rainfall and the $\mathrm{R}$ squared value shows a $2.5 \%$ variation in rainfall indicating that the regression line fits the data as shown in Figure 3. 


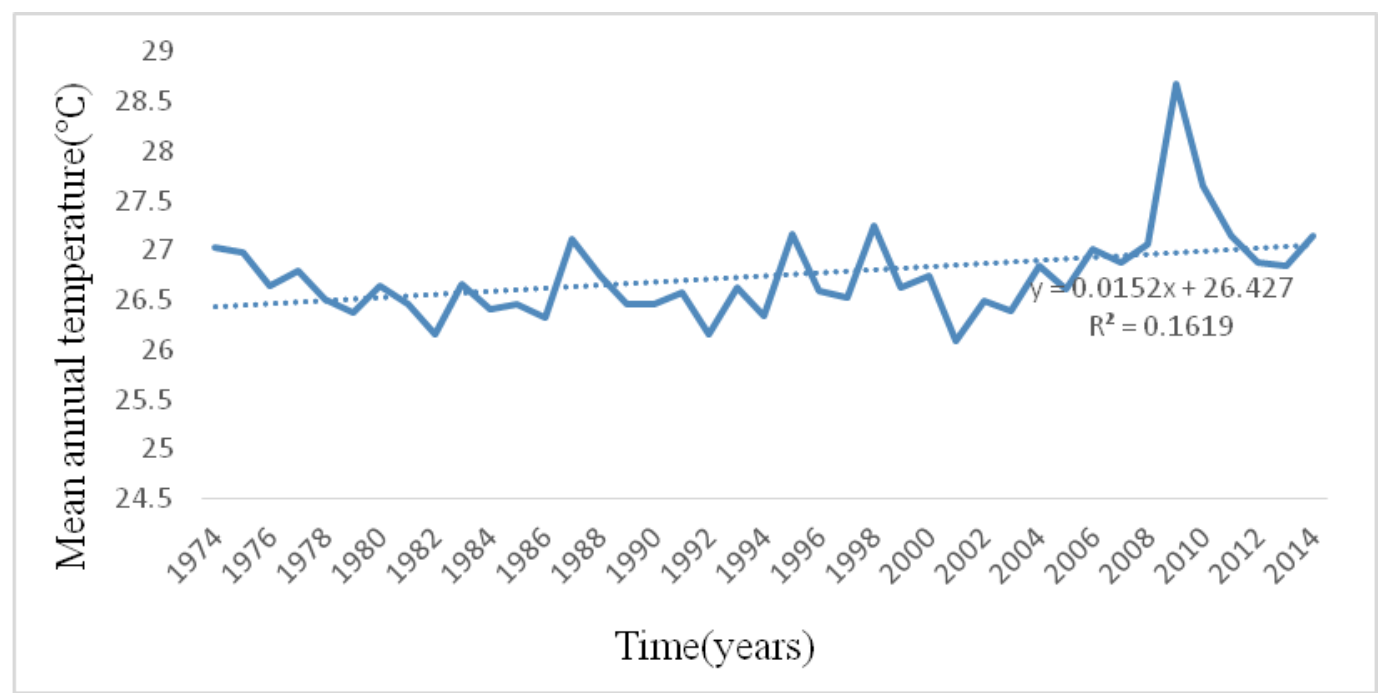

Figure 2. Mean annual temperature patterns from 1974-2014 $\left({ }^{\circ} \mathrm{C}\right)$

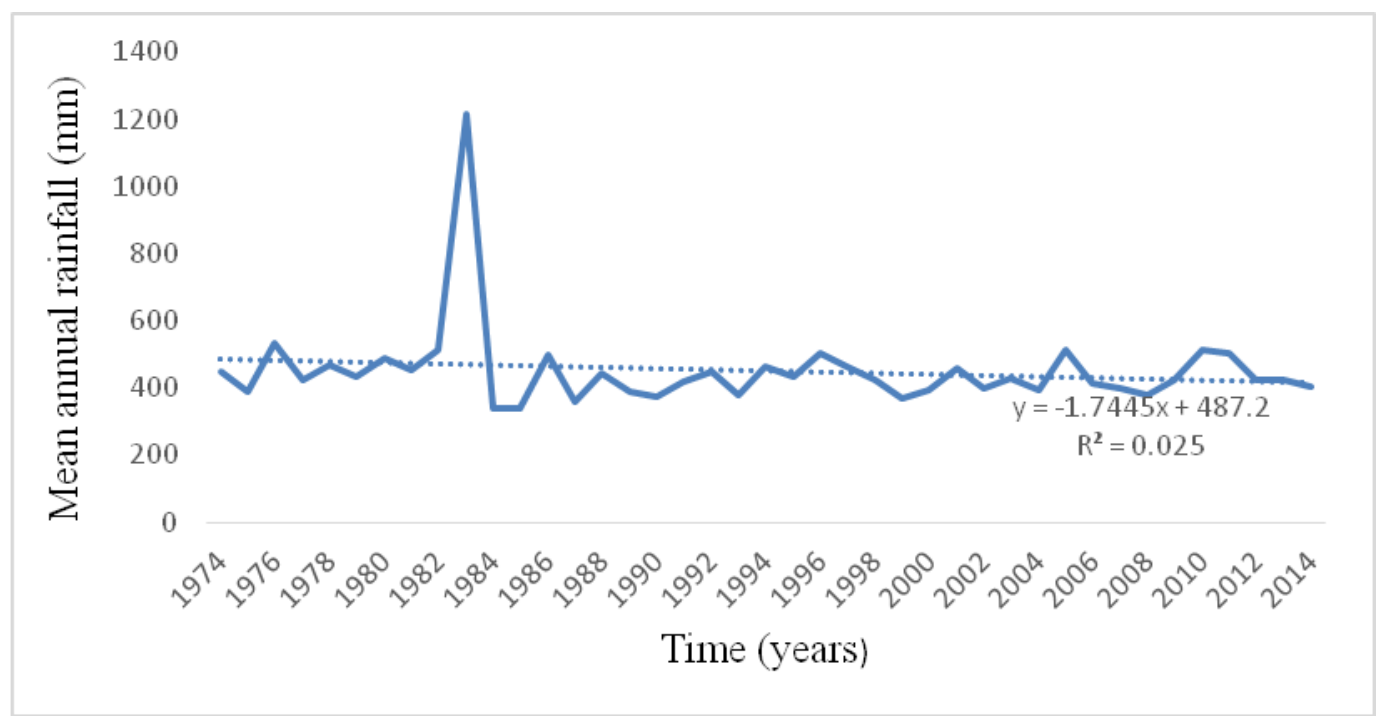

Figure 3. Trends in mean annual rainfall from 1974-2014

\section{Variation in mean annual number of rainy days}

The number of rainy days from 1974-2014 shows (Fig. 4) slight variability and decreases by about 0.0178 days per year with 1993 having the lowest mean annual number of rainy days. The $\mathrm{R}$ squared value shows a $2.46 \%$ variation in the number of rainy days.

\section{Climate adaptation strategies}

The various climate adaptation strategies included increase in farm size (land area under cultivation), use of external inputs (labour, pesticides, fertilizers, and manure), crop diversification, changing of planting dates, off-farm activities such as public transport (commercial motor bikes), and petty businesses (hair beauty salons, barber shops, restaurants), and NTFPs harvesting. 


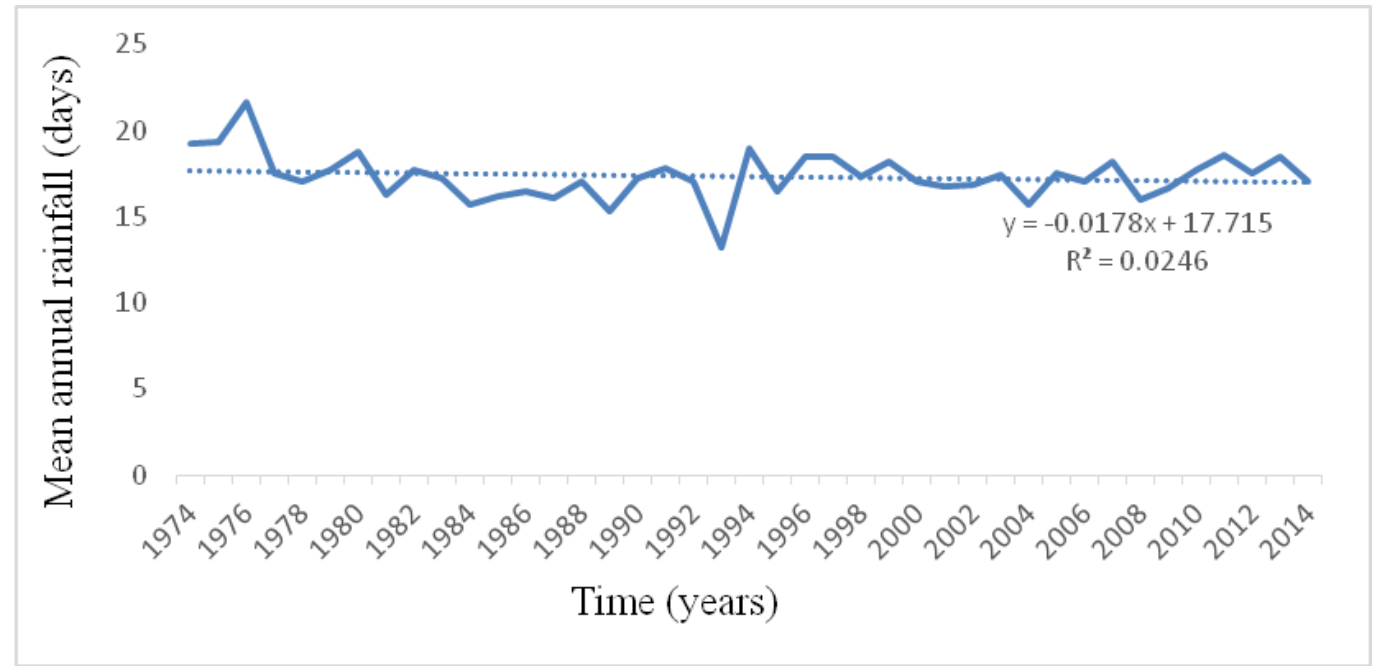

Figure 4. Mean annual number of rainy days from 1974-2014

Over $31.8 \%, 21.7 \%$ and $20.6 \%$ have adopted crop diversification, off-farm activities and NTFPs harvesting. Meanwhile, 9\%, 5.9\% and 3.4\% had adopted increase in farm size, use of external inputs and changing planting dates as climate adaptation strategies (see Table 4).

\section{Determinants of household adaptation strategies}

Various determinants of climate adaptation strategies were identified using the logit regression model (Table 5). The logit regression model showed marital status (P-value 0.072) to influence a farmer's decision to adopt increase in farm size more than gender of household head (P-value 0.221) in the village at the $95 \%$ level of significance. Similarly, age of household head (P-value 0.086) influenced the decision to adopt changing planting dates more than gender (P-value 0.207). Additionally, marital status ( $\mathrm{P}$-value 0.128 ) was more important in the decision to adopt crop diversification than age of household head (P-value 0.187).

\section{Discussion}

\section{Household characteristics of respondents}

Male headed households were higher than the female headed households due to the tedious nature of farming activity that entails more energy and physical strength. Also, female headed household heads are usually involved in other livelihood activities such as petty businesses and NTFPs harvesting. Majority of the farmers were aged between 31-60 years representing the economically active and working age group. This group has the potential to increase crop productivity by willing to adopt measures aimed at mitigating climate impacts. According to Sofoluwe et al. (2011), individuals in the active working age group have been found to be more knowledgeable about better practices and may be more willing to bear risk and adapt to better farming techniques because of their longer planning horizons. Post primary education was quite low indicating that most youths immediately take up farming after completing primary school. Their choice of selecting climate adaptation practices is usually compromised 
due to lack of access to climate information and knowledge. This is because education increases a farmer's ability and competence in efficient resources use. From another perspective, the allocative effect of education enhances a farmer's ability to obtain, analyze and interpret information (Sofoluwe et al., 2011).

Table 4. Climate adaptation strategies

\begin{tabular}{c|c|c}
\hline Strategies & Frequency & Percentage \\
\hline Increase in farm size & 32 & 9.0 \\
NTFP harvesting & 73 & 20.6 \\
Crop diversification & 113 & 31.8 \\
Changing planting dates & 12 & 3.4 \\
Off-farm activities & 77 & 21.7 \\
Use of external inputs & 21 & 5.9 \\
No adaptation & 27 & 7.6 \\
\hline
\end{tabular}

Table 5. Logit regression of determinants of climate adaptation strategies

\begin{tabular}{c|c|c|c|c|c|c|c}
\hline $\begin{array}{c}\text { Explanatory } \\
\text { variable }\end{array}$ & $\begin{array}{c}\text { NTFPs } \\
\text { coef. } \\
\text { p-value }\end{array}$ & $\begin{array}{c}\text { Crop } \\
\text { diversification } \\
\text { coef. } \\
\text { p-value }\end{array}$ & $\begin{array}{c}\text { Changing } \\
\text { planting } \\
\text { dates coef. } \\
\text { p-value }\end{array}$ & $\begin{array}{c}\text { Off-farm } \\
\text { activities } \\
\text { coef. } \\
\text { p-value }\end{array}$ & $\begin{array}{c}\text { Use of } \\
\text { external } \\
\text { inputs coef. } \\
\text { p-value }\end{array}$ & $\begin{array}{c}\text { Increase in } \\
\text { farm size } \\
\text { coef. } \\
\text { p-value }\end{array}$ & $\begin{array}{c}\text { No } \\
\text { adaptation } \\
\text { coef. } \\
\text { p-value }\end{array}$ \\
\hline \multirow{2}{*}{ Gender } & -0.193 & -0.134 & 0.804 & -0.060 & -0.146 & 0.460 & 0.217 \\
& 0.477 & 0.575 & 0.207 & 0.819 & 0.751 & 0.221 & 0.627 \\
\hline Age of & 0.006 & -0.015 & 0.065 & 0.004 & -0.005 & 0.003 & 0.004 \\
household heads & 0.641 & 0.187 & $0.086 * * *$ & 0.712 & 0.844 & 0.864 & 0.847 \\
\hline \multirow{2}{*}{ Inhabitants } & 0.258 & 0.007 & -0.263 & -0.119 & 0.307 & 0.105 & -0.818 \\
& 0.422 & 0.981 & 0.786 & 0.727 & 0.588 & 0.804 & 0.205 \\
\hline \multirow{2}{*}{ Education } & -0.033 & -0.062 & 0.353 & 0.084 & -0.325 & 0.111 & 0.052 \\
& 0.856 & 0.695 & 0.386 & 0.648 & 0.233 & 0.702 & 0.854 \\
\hline \multirow{2}{*}{ Marital status } & -0.088 & 0.217 & -0.402 & 0.001 & -0.006 & -0.324 & 0.114 \\
& 0.572 & 0.128 & 0.333 & 0.994 & 0.983 & $0.072 * * *$ & 0.634 \\
\hline \multirow{2}{*}{ Constant } & 0.780 & 1.328 & 1.192 & 1.197 & 4.244 & 1.494 & 2.714 \\
& 0.255 & 0.068 & 0.571 & 0.113 & 0.000 & 0.225 & 0.072 \\
\hline
\end{tabular}

$* * *, * *, *$ indicate significant at $1 \%, 5 \%$ and $10 \%$ significant level, respectively

\section{Perception of climate variability}

Over time, farmers have observed climate changes usually based on recent climatic events which shape their perceptions and hence adaptive decisions. Perception is thus an essential precondition to undertake adaptation measures such as the existence of longterm changes in temperature, rainfall patterns, and number of rainy days.

\section{Climate variability}

Trends in temperature and rainfall between 1974 and 2014 have been changing over time. This is may be due to the inter-annual fluctuations of the intertropical convergence zone which causes a shift in the annual alteration of wet and dry seasons in tropical Africa. This intertropical convergence zone (ITCZ) is an area of low atmospheric pressure that forms where the Northeast Trade Winds meet the Southeast Trade Winds near the earth's equator. Climate variability across Africa is further influenced by the 
forces and localizations of the African Easterly Jet (AEJ), the Tropical Easterly Jet (TEJ) and sea-surface temperature (SST), in the Gulf of Guinea (UNFCCC, 2007; Mukete et al., 2017; Sonwa et al., 2017)

\section{Climate variability adaptation strategies}

Majority of the farmers were aware of climate variability and had undertaken various adaptation options to cope with these negative climate effects. Major adaptation strategies included increase in farm size, use of external inputs, crop diversification, offfarm activities petty businesses and NTFPs harvesting. For instance, crop diversification provides the farmers with a wider choice of growing a variety of crops within a given area. Wondimagegn and Lemma (2016) also observed that this strategy expands production related activities on various crops, reduces the possible risk of climate variations and enables farmers to change crop types which are better suited to the prevailing climate regimes. Off- farm activities which compensated for the climate related low harvest are supplementary or complimentary activities that farmers engage in either offseason or on-season to support themselves. Studies by Ovwigho (2014) and Darota et al. (2017) also found such off-farm activities to include casual labour, transportation business, traditional dancing, palm wine taping, and petty trading. The switch to NTFPs harvesting and collection is frequent due to the mountainous nature of the area and which is surrounded by lowland and sub-montane forests. Mukete et al. (2018b) also observed that aside being a measure to reduce the negative effects of climate, farmers also depend on the NTFPs harvesting and collection to supplement household income, medicines and fodder for their animals.

\section{Determinants of adaptation strategies}

Perception of climate variability is directly proportional to the age of the farmers and older respondents are more efficient in perceiving climate variability than the younger respondents. Therefore, as a farmer aged, his or her ability to correctly describe climatic variations increases. A similar study by van der Veen (2013) observed the likelihood of taking up climate adoption measures to be higher among older farmers. She found the coefficient of marital status to positively correlate with the probability of a farmer selecting increase in farm size as an adaptation strategy. Thus, married farming households with large active household sizes would have more available labour force to extend farm sizes. Similarly, farming households could have access to credit schemes to increase their farm size and pay for hired labour. In Kenya, Korir and Ngenoh (2019) found married household heads to exert a significant and positive influence on the adoption of community-based climate adaptation strategies.

\section{Conclusions}

In climate change studies, it is necessary to incorporate local farmer perceptions and meteorological data particularly with respect to its influence on agriculture. As such, these perceptions can be used to examine the impact of climate on crop yield or production and various adaptation strategies employed by farmers after perceiving climate variations. As a result of climate variations, farmers have perceived fluctuations in temperature, rainfall and number of rainy days. These fluctuations have been in the form of decreased rainfall, number of rainy days with an increase in mean annual 
temperatures. Just as observed in farmer perceptions, meteorological data also showed variations. Mean annual rainfall decreased by $1.7445 \mathrm{~mm}$ per year with 1983 having the highest mean annual rainfall. Also, mean annual temperature had increased by $0.015^{\circ} \mathrm{C}$ per year with 2009 recording the highest mean annual temperatures while the number of rainy days decreased by about 0.0178 days per year with 1993 having the lowest mean annual number of rainy days. This study also observed that farmers employed various adaptation measures to mitigate perceived aspects of climate change. These strategies included crop diversification, off-farm activities, NTFPs harvesting, increase in farm size, use of external inputs and changing of planting dates.

In addition, household head's characteristics such as marital status and age affected his or her decision to adopt a particular adaptation strategy. The study has also confirmed the importance of combining and including farmer perceptions with climate and meteorological data in climate studies especially in the context of agricultural resilience to climate change as described by many scientific literatures. It has further provided knowledge of the main adaptation strategies used by farmers in the highlands of southwest Cameroon to adapt to climate change. From these adaptation strategies, effective and appropriate policies can be designed and implemented to reduce the effects of climate variability or changes. Areas for further scientific investigation in the study area could include how creating awareness of climate change and variability can influence farmers' choice of adaptation measures.

Acknowledgements. This study was financed by the World Wildlife Fund and Russel Train Fellowship for Nature (WWF/EFN) Grant No. ST60.

Conflict of interests. The authors declare that there is no conflict of interests regarding this paper.

\section{REFERENCES}

[1] Balgah, R., Kimengsi, J., Wirbam, B., Antonia, F. (2016): Farmers' knowledge and perceptions to climate variability in North West Cameroon. - World Journal of Social Science Research 3(3): 261-273.

[2] Darota, N., Ngwe, S., Fomekong, L. (2017): Comparative perception and knowledge of smallholder farmers on climate change and variation: case of Kaka (A) and Bulu (B) tribes Eastern Meyomessala sub-Division of Cameroon. - Biodiversity 1(3): 00014. DOI: 10.15406/bij.2017.01.00014.

[3] Defang, T., Amungwa, F., Manu, I. (2017): Farmers' perception of climate change and adaptation options in Southwest Cameroon. - International Journal of Rural Development, Environment and Health Research 1(3): 102-115.

[4] Etongo, D., Glover, K. (2012): Participatory resource mapping for livelihood values derived from the forest in Ekondo-Titi Sub-region, Cameroon: a gender analysis. International Journal of Forestry Research 2012: 1-10.

[5] Gadédjisso-Tossou, A. (2015): Understanding farmers' perceptions of and adaptations to climate change and variability: the case of the maritime, plateau and savannah region of Togo. - Agricultural Sciences 6: 1441-1454.

[6] Greene, W. (2018): Econometric Analysis. 8th Ed. - Pearson Education Limited, UK.

[7] IPCC (2012): Managing the Risks of Extreme Events and Disasters to Advance Climate Change Adaptation. A Special Report of Working Groups I and II of the Intergovernmental Panel on Climate Change. - Cambridge University Press, Cambridge, UK. https://www.ipcc.ch/site/assets/uploads/2018/03/SREX-Chap5_FINAL-1.pdf. 
[8] Kimengsi, J., Muluh, N. (2013): A comparative assessment of the effect of climatic variations on the crops of the Cameroon Development Corporation (CDC): adaptation options. - Environment and Natural Resources Research 3(1) http://dx.doi.org/10.5539/enrr.v3n1p144.

[9] Kimengsi, J., Tosam, N. (2013): Climate variability and cocoa production in Meme Division of Cameroon: agricultural development policy options. - Greener Journal of Agricultural Sciences 3(8): 606-617.

[10] Korir, J., Ngenoh, E. (2019): Factors influencing the adaptation decisions to impacts of climate change among the Maasai pastoral community in Narok County, Kenya. Agricultural Sciences 10: 689-705.

[11] Limantol, A., Keith, B., Azabre, B., Lennartz, B. (2016): Farmers' perception and adaptation practice to climate variability and change: a case study of the Vea catchment in Ghana. - Springer Plus 5: 1-38.

[12] Mongi, H., Majule, A., Lyimo, J. (2010): Vulnerability and adaptation of rain fed agriculture to climate change and variability in semi-arid Tanzania. - African Journal of Environmental Science and Technology 4(6): 371-381.

[13] Mukete, B., Sun, Y., Ayonghe, S., Ojong, L., Itoe, C., Tamungang, R. (2017): Adaptation of women to climate variability in the southern slopes of the Rumpi Hills of Cameroon.Agriculture, Forestry and Fisheries 5: 272-279.

[14] Mukete, B., Sun, Y., Etongo, D., Sajjad, S., Ngoe, M., Tamungang (2018a): Cameroon must focus on SDGs in its economic development plans. - Environment: Science and Policy for Sustainable Development 60(2): 25-32.

[15] Mukete, B., Sun, Y., Etongo, D., Sajjad, S., Abdul, M. (2018b): Assessing the drivers of land use change in the Rumpi Hills Forest protected area, Cameroon. - Journal of Sustainable Forestry. https://doi.org/10.1080/10549811.2018.1449121.

[16] Mukete, B., Sun, Y., Etongo, D., Ekoungoulou, R., Folega, F., Sajjad, S., Ngoe, M., Ndiaye, G. (2018c): Household characteristics and forest resource dependence in the Rumpi Hills of Cameroon. - Applied Ecology and Environmental Research 16(3): 27552779.

[17] Ndiaye, G., Shaoyong, F., Mukete, B. (2018): Analysis of market liberalization and the groundnut sector in Senegal. - International Journal of Applied Agricultural Sciences 4(2): 43-51.

[18] Ofundem, T., Nkongho, R., Awono, A., Levang, P. (2017): Bush mango (Irvingia spp.): forest and on-farm resource availability and market chains in the southwest region of Cameroon. - Forests, Trees and Livelihoods 26(3): 170-182.

[19] Oluwatusin, F. (2014): The perception of and adaptation to climate change among cocoa farm households in Ondo State, Nigeria. - Academic Journal of Interdisciplinary Studies 3(1): 147-156.

[20] Ovwigho, B (2014): Factors influencing involvement in non-farm income generating activities among local farmers: the case of Ughelli South local government area of Delta State, Nigeria. - Journal of Sustainable Agriculture Research 3(1): 76-84.

[21] Seid, S (2016): Farmers' perception of and adaptation to climate change and variability: the case of Assosa District, Western Ethiopia. - Journal of Natural Sciences Research 6(17): 117-122.

[22] Sofoluwe, N., Tijani, A., Baruwa, O. (2011): Farmers' perception and adaptations to climate change in Osun State, Nigeria. - African Journal of Agricultural Research 6(20): 4789-4794.

[23] Sonwa, D., Dieye, A., El Mzouri, H., Majule, A., Mugabe, F., Omolo, N., Wouapi, H., Obando, J., Brooks, N. (2017): Drivers of climate risk in African agriculture. - Climate and Development 9(5): 383-398. http://dx.doi.org/10.1080/17565529.2016.1167659.

[24] Tabi, G., Su, Q., Mukete, N. (2017): The economic analysis of resource used efficiency for cocoa production in Cameroon. The case study of Lekie Division. - American Journal of Rural Development 5(5): 123-137. 
[25] Tsegamariam, D (2018): Climate variability and determinants of its adaptation strategies; the case of coffee (Coffea arabica) producer farmers at Abeshege Woreda, Ethiopia. Agricultural Research and Technology 17(3): 556028. DOI: 10.19080/ARTOAJ.2018.17.556028.

[26] UNFCCC (2007): United Nations framework convention on climate change. Climate change: impacts, vulnerabilities and adaptation in developing countries. https://unfccc.int/resource/docs/publications/impacts.pdf (accessed: 4 July 2015).

[27] van der Veen, T (2013): Farm level adaptation to climate change: the case of farmer's in the Ethiopian Highlands. - Environmental Management 52: 29-44.

[28] Wondimagegn, T., Lemma, S. (2016): Climate change perception and choice of adaptation strategies. - International Journal of Climate Change Strategies and Management 8(2): 253-270.

[29] Zephania, N., Bonglam, C. (2016): Perception and adaptation adjustments to climate variability within the Santa Agrarian Basin in the western highlands of Cameroon. Journal of Humanities and Social Science 21(12): 26-34. 